\title{
Alain Badiou: Çağdaş Zamanlarda Felsefe ve İmkânı
}

\begin{abstract}
Adnan Akan
Özet: Çağdaş dönemin dikkat çekici Fransız filozoflarından olan Alain Badiou, felsefeyi ve onun temeli olan hakikat fikrini her türlü son iddiasına karşı muhafaza etmeye çalışır. Bu muhafaza, ne tutucu bir tavır ne de felsefe tarihine yönelik bir nostalji değildir. Felsefenin dört temel koşulu ve içinde bulunulan çağ dikkate alınarak gerçekleştirilen bir muhafazadır. Badiou, çağın sosyo-kültürel, ekonomipolitik sorunlarının yanı sıra felsefenin içinde bulunduğu krizle hesaplaşabilecek bir felsefi tavır sunmaya çalışır. Dolayısıyla felsefenin ne olması gerektiğinin belirlenmesi çağın çeşitli felsefi eğilimleriyle veya felsefeye dair yaklaşımlarıyla hesaplaşılmasını gerektirmiştir. Bu gereklilik Badiou'yu felsefenin tanımını, gayesini, arzusunu ve koşullarını açıklamaya taşır. Nihayetinde Badiou'da felsefe, Nietzsche, Heidegger ve Wittgenstein'ın etkisi altındaki çağdaş sofizme karşı çă̆daş Platonculuk'tur.
\end{abstract}

Anahtar Kelimeler: Badiou, felsefe, hakikat fikri, felsefenin koşulları, çağdaş felsefe

Abstract: Alain Badiou who one of the remarkable French philosopher of contemporary period is tries to maintain philosophy and its basis is the idea of truth against the every claim of last. This preservation is nor a conservative attitude or not a nostalgia for the history of philosophy. It is realized by take into consideration the four basic condition of philosophy and in the current era. Badiou is trying to submit a philosophical attitude that it will be able to deal with the crisis of philosophy as well as socio-cultural, economic and political problems of era. Consequently determination of what philosophy should be is required to struggle with the philosophy trends of era and approaches to philosophy. This requirement is lead Badiou to explain to definition, purpose, conditions of philosophy and desire for philosophy. As a result the philosopy of Badiou is contemporary Platonism opposite to contemporary sofism which under the influence of Nietzsche, Heidegger and Wittgenstein.

Keywords: Badiou, philosophy, the idea of truth, conditions of philosophy, the contemporary philosophy.

\section{Giriş}

Çağdaş dönemin dikkat çekici filozoflarından olan Alain Badiou'ya göre Akan, Adnan. (2016). Alain Badiou: Çağdaş Zamanlarda Felsefe ve İmkânı. Kilikya Felsefe Dergisi 3. ss. 27-46. 
felsefe, mantıklı isyan olup adaletsizliğin, dünyanın ve hayatın içinde bulunduğu kusurlu durumun karşısına düşünceyi aklı muhafaza edecek ve son tahlilde yeni bir mantık önerecek bir hareketle çıkartır (Badiou 2016, s.11). Badiou açısından felsefe, yerleşik bir düşünsel düzeni tersine çeviren ve makbul değerlerin ötesinde yeni değerler yaratan ve köklü bir normatif ayrım yaparak tüm teorik ve pratik deneyimleri yeniden düzenleme edimi olarak tanımlanır (Badiou 2013, s.21).

Badiou'da felsefe konuşan kişinin işgal ettiği konumdan bağımsız bir söylemdir. Bu söylem, kralın, papazın, peygamberin ve tanrının söylemi değildir. Bu bakımdan, felsefeye aşkınlık, iktidar ya da kutsal işlev bakımından verilmiş bir teminat olmadığ gibi felsefe hakikat arayışının da herkese açık olduğunu varsayar. Felsefede esas olan konuşan kişinin konumu değil konuşulanın içeriği olup felsefe meşruiyetini kendinden alan bir söylem olmaktadır (2013, s.33-34). Badiou, felsefenin bu demokratik ve evrensel niteliğine karşın felsefenin hedefleri veya ereği söz konusu olduğunda bu denli demokratik olmaya razı gelmeyeceğine dikkat çeker. Ona göre, herhangi biri bir felsefeci veya felsefenin muhatabı olabilse de bu herhangi bir kanaatin en az bir değer kadar değerli olduğunu ifade etmez. Badiou şüphesiz ki bu yargısında Nietzsche'den beslenen hakikatin değil yorumların bulunduğu tezini ve çok anlamlılığı hedef alır. O halde felsefenin nihai amacı Platon'un da işaret ettiği üzere, hakikat ile kanaat arasındaki ayrımı tam anlamıyla açıklığa kavuşturmaktır. Fakat bu gaye, için kanaat özgürlüğü denen o büyük demokratik ilkeye işık tutan felsefi yorumla mümkün değildir. Nihayetinde Badiou için felsefe kanaatlerin çoğulluğu ve göreliği karşısında hakikatin birliği ve evrenselliğini koyar (2013, s.35). ${ }^{1}$ Bu bakımdan Badiou içinde bulunduğu çağın sosyo-kültürel, ekonomi-politik sorunlarının yanı sıra felsefenin içinde bulunduğu krizle hesaplaşabilecek bir felsefi tavır sunmaya çalışır. Dolayısıyla felsefenin ne olması gerektiğinin belirlenmesi çağın çeşitli felsefi eğilimleriyle veya felsefeye dair yaklaşımlarıyla hesaplaşılmasını gerektirmiştir. $\mathrm{Bu}$ gereklilik ise Badiou'yu felsefenin tanımını, gayesini, arzusunu ve koşullarını açıklamaya taşır.

\section{Badiou'da Felsefenin Arzusu ve Koşulları}

Badiou'da felsefenin içinde bulunduğu son fikrinden kaynaklı krizden

Badiou açısından, felsefe ve siyaset alanında geçerli bir siyasetin özelliklerinin eşitlik ve evrensellik olduğu görülür ve bunun klasik adı adalettir. Adalet her türlü durumu evrenselliği tescilli bir eşitlikçi norm 1şığında incelemektir. Adalet kolektif olanın hakikati olarak siyasetin felsefi adıdır ve adalet özgürlükten daha önemlidir (Bkz. Badiou 2013, s.37). 
kurtuluşu için öncelikle yapılması gereken onun arzusunu ve koşullarını tanımlamaktır. Felsefenin arzusunun tanımlanması bir bakıma felsefenin temel ayırıcı vasıflarının tanımını, koşullarının belirtilmesi ise felsefenin kendisini araçsallaştıran çeşitli eğilimlere karşı kendini ve gayesini net olarak sunmayı mümkün kılacaktır.

\section{Felsefenin Koşulları}

Badiou'da felsefenin koşullarını açıklamadan evvel onun bu çerçevede insanı nasıl ele aldığına değinmek gerekmektedir. Ona göre, insan varlığında, yalnızca olduğu haliyle dünyanın nezdinde özdeşliği zorunlu olarak insan dişı görünen projelerin veya usullerin dayanak teşkil ettiği varlıktır ve insan insanlıkla ilişkisi olmayan insan dışı rastlantıdır. Bununla birlikte insanı çeşitli durumlarda durumların varlığında başka bir şeyin vuku bulmasını sağlayan şey tarafından çağrılmışçasına çağıran temel insan-dış1lı ise hakikat veya türeyimsel usuldür (Badiou 2015 a, s.27). Dolayısıyla ana gayesi hakikat olan ve insana özgü bir düşünsel etkinlik olan felsefe bilginin hakim olduğu günün ardından gerçek yaşama özgü deneylerin gününden sonra gece çöktügünde insan-dışı koşullar bağlamında çıkagelen disiplindir (2013, s.11). ${ }^{2}$

Badiou'da felsefenin aynı zamanda da hakikatin dört koşulu bulunmaktadır. Bu dört koşul felsefenin inşası için zorunlu olarak sunulurken felsefe açısından önemli bir değere sahip matematik, şiir, politik icat ve aşktır. Badiou bu koşulları varlık ve olay merkezinde yer aldığını ifade ettiği nedenlerden ötürü türeyimsel usuller olarak adlandırırken bu türeyimsel usuller günümüz bağlaminda hakikatleri üretmeye elverişli usulleri belirleyip sinıflandırırlar (Badiou 2015b, s. 23).

Badiou'ya göre, felsefenin kendini koşullandıran hakikat koşulları arasında bir geçiş veya zihinsel bir devri daim rejimi tanımlayabilmesi için gereken serbest oyunun tıkanması veya sınırlanması felsefenin askıya alınmasına yol açar. Böyle bir olumsuzluğun en sık karşılaşılan nedeni bu koşulların sunmuş olduğu hakikatlerin birlikte-olanaklılık alanı inşa etmek yerine felsefenin kendi işlevlerini bu dört koşuldan birine ya da

2 Örnek olarak Badiou açısından felsefenin Yunan dünyasında doğup gelişmesinin temel nedeni bu koşullar çerçevesinde değerlendirilir: Ona göre, Yunanistan'ın benzersizliği kökenlere dair anlatıyı dünyevileştirmiş ve soyut sözle kesintiye uğratmış, şiirin saygınlığını matematiğin saygınlığıyla sarsmış, Kenti açık, ihtilaflı ve sahipsiz bir erk olarak kavramış ve tutkunun fırtınalarını kamu sahnesine taşımış olmasından ileri gelir. Bkz. (Badiou 2015b s.22). 
diğerine devretmesi, düşüncenin bütünü tek bir türeyimsel koşula bırakmasıdır. Badiou terminolojisinde bu tip durumlar dikiş olarak adlandırılır. Felsefe ne zaman koşullarından birine dikişlenmişse o zaman askıya alınmış ve bir alanı özgürce inşa etmekten men edilmiş olur (2015b, s. 55).

Badiou'nun işaret etmiş olduğu dikişlenme, felsefenin kendi özgünlügünü ve amacını yitirerek araçsallaştırılması anlamına gelir. Bu bakımdan Badiou'ya göre, 19.yüzyıl büyük ölçüde çeşitli dikişlerin çağı olmuştur. Bilimden zamanın hakikatlerinin tamamlanmış sistemini kendi başına şekillendirmesini bekleyen pozitivizm önemli dikişlerdendir. Felsefenin pozitivizmle bilimsel koşuluna dikişlenmesi onu nihayetinde analitik ekolun Badiou'da eleştiriye tabi tutulacak sınırlılığına, tek yönlülügüüne indirgemiştir (2015b, s.55).

Badiou'nun dikiş sorunu çerçevesinde değindiği önemli eğilimler arasında Marksizm de bulunur. Ona göre, hâkim tarihsel anlatı ve politik tavrıyla Marksizm felsefeyi kendi politik koşuluna dikişlemiştir. Dünyanın yorumu yerine devrimci dönüşümü veya praksisi merkeze alan iddia felsefenin politikayla dikişlenmesine yol açmıştır. Burada politika felsefi olarak genel anlam sistemini fiilen şekillendirmeye yetenekli tek şey olarak tanımlanırken felsefe ise pratiğe bağlanarak, Badiou'nun ifadesiyle meyve vererek yok olmaya mahkûm edilmiştir (2015b, s.56-57).

Badiou'ya göre, Hegel'den beri askıya alınma çarkına girdiyse bunun temel nedeni felsefenin anlatıldığı tarzda kendi koşullarından birinin etkisi altına girmiş olması ve bu koşulların genel birlikle olanaklılıklarını şekillendirmekten onu meneden bilimsel ve tarihsel koşullarında dikişlenmesinin ağında tutsak kalmasıdır. Bu durumda, felsefenin sistematik biçiminin artık mümkün olmadığı ifade edilir. Bu son, ya bilimsel dili merkeze alan analitik ekolce ya yoruma dikkat çeken dili merkeze alan yorumsamacı ekolce veya eylemi önceleyen Marksist ekolce dile getirilir. Dolayısıyla Badiou'nun işaret ettiği dikişlenme felsefenin çeşitli ekollerce önceden belirlenmiş amaçlara göre araçsallaştırılması anlamına gelirken felsefenin kendi koşullarını bir bütünsellik çerçevesinde ele alması mümkün görülmez.

Badiou açısından felsefe, bir toplum bilimden, güncel siyasal tartışma biçimlerinden farklı olarak kendi problemlerini oluştururken gerçek bir filozof ise herkes için önemli ve yeni problemlerinin kendi hesabına, 
özgün bir şekilde kararını veren ve sunan kişidir (Badiou-Zizek 2005, s.1). Badiou sanıldığı üzere hemen herşey üzerine dile getirilecek olan düşüncelerin felsefi olarak tanımlanamayacağını dile getirir. Ona göre, felsefe yeni problemlerin inşası için filozofun karşılaştı̆̆ 1 işaretlere bir müdahalesini gerektirmektedir. Badiou, bu müdahalenin nasıl olduğunu üç ayrı örnek üzerinden açıklamaya çalışır.

Badiou'nun felsefi durumla alakalı sunduğu ilk örnek, Gorgias diyalogunda Sokrates ve Kallikles arasında mutlu bir insanın bir tiran mı yoksa adil bir adam mı olduğu üzerine yaşanan tartışmadır. Badiou açısından bu salt bir tartışma olmaktan ziyade bir meydan okuma iken bu meydan okumada felsefenin görevi bize seçim yapma zorunluluğunu göstermesidir. Burada felsefe, Kallikles'in ve Sokrates'in iddiası üzerine seçim yapılmasını, kimden yana olunduğunun karar verilmesini talep eder. Badiou için, bu örnekte, felsefe bir seçim olarak düşünmeyi bir karar olarak düşünmeyle yüz yüze getirir. Onun görevi, seçimi aydınlatmaktır. Böylelikle bir felsefe durumun bir seçimin açıklandığı, aydınlatıldığ 1 bir seçim anından oluştuğu söylenebilir (Badiou-Zizek 2005, s.2-3). İkinci örnek, Roma'nın Sicilya işgaline karşı diren matematikçi bilim insanı Arşimet'in işgal komutanı General Marcellus'un kendisini görmek istediğini ileten asker karşısında o an sürdürmekte olduğu matematiksel çalışma ve deneyini öncelemekte gösterdiği tavırdır. Bu tavır onun ölümüne neden olmuştur. Bununla birlikte Badiou'nun bu trajik vakadan çıkarmak istediği husus ise, hakikat ile politik güç arasında ortak ölçüsü olmayan bir mesafenin var olduğudur. Dolayısıyla felsefeye düşen bu mesafeyi aydınlatmaktır (2005, s.4-5; Badiou 2006, s.6). Badiou'nun verdiği son örnek ise, Japon yönetmen Mizoguchi'nin The Crucified Lovers adlı filmidir. Aşk üzerine yapılmış en iyi film olarak betimlediği bu filmde genç bir kadın küçük bir atölyesi olan dürüst bir adamla evli olmasına karşın kocasını sevmemekte ve kocasının çalışanlarından olan genç bir adama âşıktır. Bu durum toplumun mevcut yasalarına göre ölümle sonuçlanması gereken bir suçtur. Dürüst ve eşini seven kocanın bütün gayretine karşın, aşıklar işkenceyle katledilir. Badiou'nun betimlendiğine göre, bu iki aşığın yakalanmış oldukları ve işkence içerisinde olmalarına karşın yüzlerinde bir gülümseme vardır. Badiou için bu gülümseme aşık ölüme direnendir ilanını bize sunarken bu örnekle yaşamın sıradan kuralları ile aşk olayı arasındaki ölçülemeyen bir ilişkiyle karşılaşırız. Bu durumun felsefenin tanımlanması açısından değeri ise felsefenin olayı ve istisnayı düşünmemiz gerektiğini bizden talep etmesi bağlamında kendisini sunar. Toplumsal tutuculuğun, sıradanlığın ötesine geçen olayı, olağanüstünü 
düşünmektir (2005, s.5-7; Badiou 2006, s.7).

Badiou'nun felsefeyi, kendi koşulları karşısında değerini muhafaza etme gayreti ve verdiği tarihsel örnekler dikkate alındığında ilk etapta felsefeyi geleneksel felsefede felsefenin çeşitli bilimlerin ilkelerini kendisinden aldıkları bir üst şemsiye ve dünya üzerinde genel bir çerçeve sunma çabası olarak bir metafizik olarak tanımlanmasında olduğu gibi ele almaya çalıştığı düşünebilinir. Fakat Badiou kendi hakikat kuramı da dikkate alındığında klasik felsefeden farklı bir noktada durur. Onun savunduğu, şiir, matematik, politika ve aşkta yaşanan olayların sunduğu hakikatlerin eş zamanlı olacak şekilde bir bağlamda ele alınmasıdır. Zira ona göre felsefe hakikatlerin varının ve bu hakikatlerin birlikte oluşlarının dile geldiği düşünce yeridir. Bunu yapmak için felsefe işlemsel bir kategori olarak hakikati oluştururken hakikat kategorisi düşüncede aktif bir boşluk açar. Söylem olarak felsefe ise bir bilgi kurgusu ile bir sanat kurgusunun üst üstüne konuşunu düzenler. Felsefe bu iki kurgulamanın ardındaki mesafenin ya da aralığın açtığı boşlukta hakikatleri yaklar ve bu eylemle hakikatlerin var olduğunu duyurur ve bu varın düşünceyi kavramasını sağlar. Nihayetinde bilgi kurgusu olarak felsefe matematiği, sanat kurgusu olarak da şiiri taklit eder. Bununla birlikte, bir edimin yoğunluğu nesnesiz bir aşk gibi iken hakikatlerin varlığının yakalanışından herkes nasibini alsın amaciyla herkese hitap etmesiyle de iktidar hedefi olmayan siyasi bir strateji gibidir (2016, s.117). O halde felsefe zaman ve mekan ötesi tek bir hakikatin değil koşullarına özgü hakikatler çokluğunu ortak bir bağlam etrafında bir araya getirme çabasını imler. Bir bakıma tarihsel ve kültürel göreliliğin ötesinde olan biricik hakikat inancı olmaktan ziyade hakikatler çokluğunun ortak bir bağlamca bütünselleştirilme çabasıdır. Bu bakımdan, Badiou'nun felsefi tutumu ve hakikat arayışını belirleme çabasında kendisini etkileyen koşullar, Matematik açıdan Cantor-GödelCohen'de şekillenen kümler kuramı, aşk kavramı açısından Lacan, şiir açısından Pessoa, Mandelstam, Celan, politik icat açısından 1965-1980 arasındaki karanlık olaysallıklar kesitidir $(2015 \mathrm{~b}, \mathrm{s.87}){ }^{3}$

\footnotetext{
3 Badiou felsefe ve koşulları arasındaki tezini desteklemek açısından tarihteki kimi olaylara başvurur: Eudoksos'un geometrisi ve Post-Pisagorcu sayı ve ölçü kavramının hakim olduğu bir dönemde Platon duyumsanabilir ile anlaşılabilir arasında bir ayrım yapılmasını önermişti. Fransız devriminin yeniliği karşısında Hegel mutlak ideaya tarih ve oluş fikrini katmıştı. Wagner'in müzikal dramasının ondan uyandırdığı coşkulu hisler karşısında Nietzsche Yunan trajedisi ile felsefenin ortaya çıkışı arasında diyalektik bir ilişki tasavvur etmişti. Diş̧il boyutun gitgide artan vekaçınılmazönemikarşısındaDerrida insan deneyiminikatımetafizikkarşıtlıklar çerçevesinde değerlendiren klasik yaklaşımı dönüştürmüştü. Bkz. (Badiou 2013, s.23-24).
} 


\section{Felsefe ve Dört Arzusu}

Felsefenin kendisini tanımlayan dört boyutlu arzusu olduğunu ifade eden Badiou için bunlar, isyan, evrensellik, mantık ve risktir. Öncelikli olarak felsefenin arzusu, dünyanın mevcut haline karşı derin bir hoşnutsuzluğa imkân tanıyan bir isyandır. Bununla birlikte bu isyan kaba, gelişigüzel ve temelsiz bir isyan olmayıp felsefe ayn zamanda muhakeme ve aklın gücüne duyulan bir inancı da içerir (2016, s.11). O halde felsefe mantıklı bir isyan olduğu gibi mevcut haliyle dünyaya ve yerleşik kanaatlerin diktatörlüğüne karşı bir ayaklanmayı ifade eden devrim arzusuyla bir ussallık gerekliliğinin birleşimidir. Felsefi arzu, düşüncede, varoluşta, kolektif hayatta ve kişisel hayatta bir başkaldırma tutkusudur. Badiou'ya göre Platon'dan bu ana kadar felsefe dünyanın adaletsizliğine ve insan yaşamının sefaletine karşı duran ama tüm bu karşı duruşları tartışmanın, kanıtlamanın hakkını koruyacak bir eylem içinde ve mutluluğun gerçek olanını görünüşte olanından ayırmasını mümkün kılan mevcut eylemlikte yeni bir mantık önererek yapmaktadır (Badiou 2015c, s.17).

Felsefe, bütün insanların düşündüğü varsayımı üzerinden bütün bu insanlara hitap eder. Ayrıca felsefe evrenseli-tümeli düşünmeyi ve gerçekleştirmeyi talep eder. Her şeyden önce evrensel olmayan, bunun bir öznesi hâline gelmeye muktedir tüm diğer insanlar tarafından paylaşılma olanağını dışlayan bir mutluluk gerçek bir mutluluk değildir (2015c, s.18). $\mathrm{Bu}$ husus da felsefenin evrensellik arzusunu ifade eder. Mantıklı isyan ve evrenselliğin dışında son olarak felsefe risk alır.

Badiou, felsefenin dört arzusunu bu şekilde tasnif ettikten sonra bu dört arzuyu dünyanın içinde bulunduğu somut durumlar karşısında ele alır. Öncelikle Badiou açısından özellikle Batı dünyası, düşünme faaliyetinde isyandan kopuk bir durumdadır. Bu dünya başkaldırıya uygun olmayan bir yapıya sahiptir, fakat bunun nedeni başkaldırının olmaması değil, Batı dünyasının mensuplarına ve kuşatmış olduklarına sunduğu yanılsamadan ötürüdür. Buna göre, bu dünya kendini özgür bir dünya olarak sunarken, radikal bir anlamda daha iyisinin istenmesine veya umut edilmesine gerek duyulmadığını iddia ediyor. Bununla birlikte Badiou için bu dünya bu özgürlüğün bahislerini tek tipleştirdiği ve ticarileştirdiği için, sunduğu özgürlük de, metaların dolaşım ağı içinde tuttuğu yerin tutsağı olmuş bir özgürlüktür. Öyle ki bu dünya, aslında, bir şekilde özgürlük tam da bizzat dünya tarafından sunulduğundan, ne özgür olmak için başkaldırma fikrine uygun, ne de bu özgürlügün 
özgürce kullanılması diye adlandırılabilecek şey için uygun bir yapıdadır (2015c, s.19). Her şeyden önce bu dünyada özgürlük kapitalist meta üretiminin ağı içerisindedir. Mevcut haliyle bu dünya bize özgürlüğü özgürce kullanma garantisi sunmadığı gibi onun bizden talep ettiği sahte özgürlük ise mal mülkün sonsuz yanılsaması tarafından kodlanmış ve yönlendirilmiş durumdadır. Bu durum, dünyanın düşünmenin itaatsizlik olabileceği fikrine yoğun bir baskı uygulamasının temel nedenidir (2016, s.12).

Dünyanın özgürlüğe yönelik bir isyan tutkusundan yoksun olduğuna değinen Badiou, mevcut haliyle düzenin felsefenin mantık boyutuna da güçlü bir baskı uyguladığına dikkat çeker. Ona göre, dünyanın son derece mantıkdışı bir iletişim rejimine teslim olmuş olması bunun esas nedenidir. Badiou için günümüzde iletişim, kopuk kopuk imgelerden, sözlerden, beyanlardan ve yorumlardan oluşan, kabul edilmiş ilkesi de tutarsızlık olan bir evren iletirken her ilişkiyi kendi akışıyla önüne katıp sürüklediği unsurlar arasında bozmaktadır. Mevcut haliyle kitle iletişimi, dünyayı bize bellekten yoksun ve imgelerin unutuluşa terk ettiği bir gösteri olarak sunmaktadır. Dolayısıyla iletişim süreçleri düşünmenin mantığa olan sadakatinin kararlılığına baskı uyguladığ $\breve{g i b i}$ düşünceye mantık yerine imgesel saçılma önermektedir (2016, s.12-13.; 2015c, s. 20).

Uzmanlaşmış ve parçalı bir dünya karşısında olduğumuzu dile getiren Badiou'ya göre, dünyamız, şeylerin teknik konfigürasyonunun sayısız dallanıp budaklanışının, üretim aygıtlarının, maaş bölüşümünün, işlev ve beceri çeşitliliğinin talepleri karşısında parçalanmış bir dünyadır. Bize aynı anda hem evrenselin soyut ve parasal bir biçimini sunan hem de bu biçim altında uzmanlaşmış ve parçalı bir gerçekliği saklayan bu dünya felsefenin evrenselliğine kuvvetli bir baskı uygulamaktadır. Ayrıca dünyanın vadettiği mutluluk belirli gruplara ve rekabet halindeki bireylere tahsis edildiği gibi bu gruplar ya da bireyler bu mutluluğu ondan hiçbir şekilde faydalanamayan kitlelere karşı miras kalmış bir ayrıcalık olarak savunmaktadırlar. Nihai olarak, Bu uzmanlaşma ve bu parçalanmanın gerekleri de bütün bu alanları çaprazlama kesebilecek şeyleri ya da evrensel, yani her türlü düşünme için geçerli olabilecek şeyleri algılamayı güçleştirmektedir (2016, s.13.; 2015c, s.21).

Düşünsel ve mantıksal isyandan, evrensellik idealinden kopuk olan dünya Badiou açısından riskli kararlardan, taahhütlerden de yana değildir. Ona göre, dünyanın bu halinde kimse kendi varoluşunu şansın 
getirebileceği tehlikelere açma imkânına sahip değildir. Var olmak daha fazla hesap kitabı gerektirdiği gibi hayat güvenlik hesaplarına bağlanmış bir vaziyettedir. Güvenlik ve hesaplama takıntısı nihayetinde kişiyi düşünmeden de risk almaktan da özgürlük tutkusundan da uzak tutmaktadır. Dünyamız, yaşamı, bu şüpheli güvenceyi sağlamak için zorunlu olarak yapılan ince hesapların eline teslim ederken, varoluşun art arda gelen kesitlerini de bu ince hesaba göre düzenler. Badiou için dünyanın bu halinde hiçbir şey, örneğin öğretimin gitgide daha fazla mesleki güvence hesabına göre düzenlenecek ve istihdam piyasasının yapısına uydurulacak şekilde örgütlenmesi kadar çarpıcı değildir (2016, s.13.; 2015c, s.21).

\section{Günümüzde Felsefenin Durumu ve Gerekliliği}

Badiou'ya göre, felsefe arzusu dünyanın mevcut halinde başlıca dört engelle karşı karşıyadır. Bu engeller, özgürlük yanılsamasıyla perçinlenmiş mal mülkün hükümranlığ1, iletişimin hükümranlığ1, teknik uzmanlaşma ihtiyacı ve gerçekçi güvenlik hesapları yapma zorunluluğudur. $\mathrm{Bu}$ engeller, hakiki yaşam ve mutluluk fikrinin de önünde engeller oluşturdukları gibi gerçekçi bir yaşamın tüketime dayalı bir tatmin görünüşüne indirgenmesine yol açarlar (2016, s.13.; 2015c, s.22). O halde cevabı aranması gereken soru, felsefenin karşı karşıya kaldığı bu dört tehdidi nasıl aşabilecek olmasıdır? Badiou'da bu sorunun cevaplanabilmesi için öncelikle felsefenin temel koşullarını belirlemek ve onun günümüzdeki yönelimlerini inceleyip kritik etmek gerekmektedir.

\section{Günümüzde Felsefi Yönelimler}

Badiou açısından günümüzde üç ayrı coğrafi bölgeye tekabül eden üç felsefi yönelim bulunmaktadır. İlki, tarihsel olarak Alman Romantizm kökenli Yorumsamacı-Hermeneutik ekoldür. Coğrafi mekânı temelde Almanya olan bu ekolün çarpıcı isimleri Heidegger ve Gadamer'dir. Badiou'nun açıkladığına göre, bu felsefi eğilim felsefeye varlığın anlamının dünyada-olmanın anlamının şifresini çözme gayesini yüklerken, temel kavram da yorum olmaktadır. Felsefe, anlamı belirsiz, gizli, örtük veya unutulmuş, ihmal edilmiş edimleri veya yazıları belirsizlikten kurtararak bu belirsizlikten sahici bir anlam çıkaracak bir yorumlama yöntemi sunmalıdır. Bu bakımdan bu felsefi eğilimde temel karşıtlık kapalı-açık karşıtlı̆̆ 1 iken verili olanda, insanın karşısında olduğu metinde bulunan kapalılığ1 anlama açmak ise temel bir gaye olarak kendisini sunar. 
Badiou'ya göre, hermeneutik ekolün sunduğu bu gaye, felsefenin dünyası ile tekniğin dünyası arasındaki bir savaşa karşılık gelir zira tekniğin dünyası kapalı nihilizmin bir başarısıdır (2016, s.14).

İkinci ekol, Viyana çevresi ile doğmuş olmasına ve dikkat çekici temsilcileri arasında Wittgenstein ve Camap'ın bulunması karşın günümüzce İngiliz ve Amerikan akademik çevrelerine hâkim olan Analitik ekoldür. Bu ekole göre, felsefenin amacı anlamı olan önermelerle olmayanları kesin bir biçimde ayırmak, söylenebilecek olanlar ile söylemenin imkânsız veya gayri meşru olduğu şeyleri birbirinden ayırmaktır. Bu bakımdan felsefenin asıl aracı önermelerin ve son tahlilde bütün bir dilin mantıksal ve dil bilgisel açıdan analizi iken temel kavram kuraldır. Bu felsefi ekolde temel karşıtlık kurallı hale getirilebilecek şeyler ile getirilemeyecek şeyler arasında veya kabul gören bir yasaya uyarak anlam hakkında uzlaşmayı sağlayan şeyler ile açık seçik hiçbir yasanın alanına girmeyip yanılsama ve uyumsuzluk yaratan şeyler arasındadır. Analitik ekol açısından felsefenin tedavi edici ve eleştirel bir amacı vardır. $\mathrm{Bu}$ tedavi edici eleştirel gaye ise, bizi anlamı olmayan şeyleri tecrit edip herkes için saydam olan kurallara dönerek, dilin bizi bölen yanılsama ve sapmalarından kurtarma işidir (2016, s.15).

Badiou için üçüncü felsefi ekol Derrida, Lyotard gibi isimleri bünyesinde taşıyan ve aktif olarak Fransa'da görülmesine karşın Latin ülkelerinde de önemli temsilcileri olan Postmodern ekoldür. Postmodern eğilim, felsefenin amacını modernliğin temel kabullerinin yapı-bozuma uğratılması olarak belirler. Bu çerçevede, ilerleme fikri, devrim inancı, insanlık ve bilim ideali gibi büyük yapı veya anlatıları yapı bozuma uğratan Postmodernlik bu anlatıların, ideallerin miadının dolmuş olduğunu, çokluk içinde yaşadığımızı, büyük tarih felsefelerinin veya metafizik sistemlerin olmadığını, eylemde ve düşüncede diller çoğulluğu olduğunu, söz konusu dilsel çoğulluğun bütünleştirilemeyecek veya uzlaştırılamayacak kadar çeşitlilik arz ettiğini iddia eder. Temelcilik ve bütünlük fikrini hedef alan bu ekol bütünsellikten arındırılmış karma pratikler olarak Badiou'nun adlandırdığı pratikleri harekete geçirirken, düşünceyi varoluşları, etrafı kuşatılamayan alanlara yerleştirir. Nihai olarak felsefeyi sanatın kıyısına yerleştirirken felsefenin kavramsal yöntemi ile sanatın duyu yönelimli girişimini bütünleştirilemeyen bir karışım içinde bir araya getirmeye çabalar (2016, s.15).

Badiou, kısaca açıkladığı bu üç felsefi yönelim farklılıklarına karşın 
iki temel ortak özelliklerinin olduğuna dikkat çeker. Bunlardan ilki, her üç yönelim de belli bir çerçevede felsefenin bizatihi felsefenin sonu içinde konumlanmış olduğunu veya felsefenin kendi kendisinin belli bir sona ulaşmış olduğunu beyan ettiğini iddia eder. Bu son düşüncesinin sunmaya çalıştığ şey, klasik felsefenin ortaya koyduğu haliyle hakikat idealinin ve metafiziğin yıkımıdır. Bu bakımdan hakikat fikri yerine anlamların çoğulluğu fikri ön plana geçerken, Badiou'ya göre, çağdaş felsefe bir bakıma hakikat yönelimli bir felsefeden anlam yönelimli bir felsefeye geçişi ifade eder (2016, s.16-17).

İkinci ortak özellik ise, çağdaş felsefenin öncelikli olarak dil üzerine, dilin yapabilecekleri, kuralları hakkında ve düşünce söz konusu olduğunda dilin nelere yetki verdiğine yönelik bir düşünme olmasıdır. Badiou için dil merkezli bu anlayış her üç felsefi ekolde kendisini apaçık bir şekilde sunar. Buna göre, hermeneutik eğilim, belli bir anlamda konuşma edimlerinin yorumlanmasından, analitik yönelim önermeler ile onları yönlendiren kurallar arasındaki ilişkiden ve nihayet Postmodern yönelim homojen bütünselliğin aksine bir cümleler, parçalar ve söylem biçimleri olan çokluk fikrinden ibaretken dil bütün bu eğilimlerde aşkın ve merkezi bir yere sahiptir ( 2016, s.17).

Badiou bu üç felsefi eğilimle temelde iki temel husus üzerinden hesaplama içerisinde bulunur. Öncelikle herşeye rağmen bir hakikat kategorisinin felsefenin içinde bulunduğu kriz durumundan sıyrılabilmesi açısından gerekliliği hususu ve öte yandan üç yönelimde de başat bir nitelik olarak kendisini sunan dille felsefenin evrenselliği açısından hesaplaşma zorunluluğudur.

Badiou'ya göre, hakikat kategorisinin anlamın çok değerliliği çerçevesinde görmezlikten gelinmesi durumunda, felsefe para ve malumat ticaretine tabi bir dünyanın kendisine yöneltmiş olduğu meydan okumaya asla karşıllı veremeyecektir. Felsefenin sermayenin anarşik bir dağılımının ve paranın, ürünlerin, imajların mübadele edildiği bir dünyada kendi arzusunu ayakta tutabilmesi için bu yapıyı kesintiye uğratabilecek bir ilkeye sahip olması gerekir. Düşünceye sonsuz dolaşım rejimini kesintiye uğratacak bir ilkenin önerilmesi gerektiğini düşünen Badiou için felsefenin kendisini bu dolaşımdan çıkarabilmesi felsefenin var olabilmesinin zorunlu bir koşuludur. Bu kesinti noktası, koşulsuz bir gereklilik olduğu gibi dolaşıma sokulamayan bir yapıya da sahiptir. Badiou'ya göre, bu koşulsuz gereklilik noktası, anlamın çok değerliliği 
iddiası veya önermesiyle desteklenemeyeceği için hakikat kategorisinin yeniden inşa edilmesi veya yeniden ortaya çıkması gerekmektedir.(2016, s.19). Hakikat kategorisinin yeniden sunulması veya inşa edilmesinin önemi Badiou'da felsefenin, insanın hesapçı hayat karşısında varoluşsal bir kumarla, özgürlük denebilecek bir değere yol açabilecek bir kumarla karşı çıkabilmeyi de sağlamasından ileri gelir (2016, s.19).

Ayrıca, Badiou için felsefenin sonunu, tamamlanmış olduğunu ve köklü bir çıkmaza sürüklenmiş bulunduğu söylemek iddia edilenin aksine alçak gönüllü bir iş değildir. Ona göre, büyük anlatıların sonunun ilanı bizzat büyük anlatının kendisi kadar tevazudan uzaktır. Bununla birlikte, metafiziğin sonunun kesinliği, kesinliğin metafizik unsuru içinde yer alırken özne kavramının yapı sökümü tarihsel buyruğu daha belirleyici olan merkezi bir kategoriyi yani varlık kategorisini gerektirmektedir (2015b, s.16). Dolayısıyla felsefenin sonunu ilan etmek bile nihayetinde felsefenin içinde yapılan bir eylemdir. Elbette ki Badiou felsefenin önemli bir krizle karşı karşıya olduğunu inkâr etmez fakat yapılması gereken nihai bir son çağrısında bulunmak, hakikat fikrini yadsımak değildir; içinde bulunulan durumu olduğu gibi kavrayıp felsefenin koşulları bağlamında çözüm sunabilmektir.

Badiou'ya göre, felsefeyi salt dil ve nitelikleri hakkında düşünmekten ibaret olarak görmek, felsefenin dünyadaki uzmanlaşma ve parçalanmanın evrenselliğin karşısında kurduğu setlerin aşılabilmesini sekteye uğratmaktadır. Dil evrenini felsefi düşüncenin mutlak ufku olarak kabul etmek çağdaş iletişiminin getirdiği parçalanma ve yanılmanın kabulüdür. Unutulmamalıdır ki dilsel çokluğun beraberinde getirmiş olduğu sav ortada dil oyunlarına bağlı olarak yorumlar çokluğu olduğudur. Bu sav felsefenin evrensellik iddiasını, arzusunu krize sokmaktadır. Dolayısıyla felsefe, bu dilsel çokluğa tabi olmamak için onun dişında bir konuma yerleşmek zorundadır. Aksi takdirde felsefe evrenselliğini yitireceği gibi dil oyunları çokluğunun salt bir tasviri olmaktan öteye gidemeyecektir. Ayrıca kimi isimlerde veya tezlerde felsefenin Grekçe ile özdeştirilme örneklerinde olduğu gibi bir dil ırkçılığına da düşebilir (2016, s.18).

Badiou, analitik ekole dile verdiği merkezi konumdan ötürü eleştirilerde bulunurken ona göre, bu ekol, anlam ve anlamsızlık arasındaki ayrımı temelde matematik ve bilimsel dilde görüldüğü gibi bir kurala büründürerek sunar. Fakat bilim diline tanınan bu köklü ayrıcalık felsefenin önemli veçhelerine karşı bir küçümsemeye, insanlığın önemli 
bir çoğunluğunun analitik ekolün savunduğu felsefi alanın dışında kalmasına ve bu gerçekliğe karşı gözleri kapama tavrına yol açmaktadır (2016, s.19).

Felsefenin içinde bulunduğumuz çağda, bu üç ayrı eğilimler çerçevesinde yapılamayacağını iddia eden Badiou'ya göre her üç eğilim de anlamın çok değerliliğine ve dilsel çoğulluğa fazlasıyla bağlı durumdadırlar. Felsefenin içinde bulunulan krizden sıyrılmayı ve mübadele çokluğundan kopmayı sağlayabilecek bir başka konumun gerekliliği Badiou'yu yorumsamacı ekolden, mantıksal dil bilgisi analizinden ve anlamsal çok değerlilikle dil oyunlarından farklı kurucu bir felsefi üslup ve yöntem arayışına taşımıştır.

Badiou'nun felsefi üslup veya yöntemi, dilin düşüncenin mutlak ufku olmadığ 1 fikrini bize sunar. Badiou, Platon'un Kratylos diyalogundan yaptığ1 bir alıntıyla felsefenin kelimeleri değil şeyleri kalkış noktası yaptığını iddia eder. Badiou için felsefenin rengi, tınısı veya çekimini her ne kadar dil verirken felsefenin vazgeçemeyeceği çok temel bir niteliği ve düşüncenin örgütlenişinin temel ilkesi dil ile düşünce arasındaki bu ilişki değildir. Temel ve vazgeçilemez nitelik, felsefi düşüncenin evrensel olarak aktarılabilirliğidir. Ayrıca felsefenin hiçbir dile ayrıcalık tanımaması gerektiği gibi felsefe katıksız biçimsel bilim dili ideali içine kapatılmış da değildir. Şüphesiz ki felsefenin doğal öğesi dildir, ama bu doğal öğe içinde evrensel bir hitap alanını da kurumsallaştırır (2016, s.21).

Badiou'ya göre, felsefenin müstakil ve indirgenemez rolü söylem içinde sabit bir nokta, bir kesinti noktası, bir süreksizlik noktası, koşulsuz bir nokta yerleştirmektir. Bu noktanın gerekçesi ise dünyanın içinde bulunduğu somut koşullardan ileri gelir. Buna göre, günümüz dünyasına damgasını vuran şey, tarihsel, teknik, iletişimsel hızdır. Bu mevcut hız, insanı büyük bir tutarsızlık tehlikesine maruz bırakırken, şeyler, imajlar ve ilişkilerin hızlı bir şekilde dolaşıma girdiği bu durumda insanın tutarsızlığın kapsamanı ölçebilecek kadar zamanı bulunmamaktadır. Dünyanın bu hızının tutarsızlığın maskesi olduğunu değinen Badiou'ya göre felsefe hızlanma buyruğu karşısından düşünceye ait bir zaman inşa etmelidir (2016, s.21). Dolayısıyla hem dünyanın içinde bulunduğu bu kaotik hal karşısında hem de felsefi eğilimlerin temel nitelikleri ve ilan ettikleri son fikri karşısında mesele hakikat kategorisini yeniden inşa edebilmektir. Bununla birlikte Badiou önemli bir hususa dikkat çeker. Inşa edilmesi gerekli olan hakikat kategorisi, metafiziğin veya klasik felsefenin 
devretmiş olduğu hakikat değil, dünyanın mevcut halini dikkate alarak yeniden kurabildiğimiz hakikattir (2016, s.21). Bunun için de Badiou çokluğu ve sonsuzluğu dikkate alan bir hakikat kuramı için matematikteki kümeler kuramı ile harmanlanmış bir olay ve varlık anlayışı sunmaya çalışacaktır.

\section{Felsefenin Gerekliliği}

Felsefenin koşullarını, arzusunu çağ içinde karşılaştığı temel problemleri ve nihayet çeşitli felsefi eğilimleri ve onların felsefeye dair yaklaşımlarını ele alan Badiou'nun herşeye karşın felsefeyi, felsefi düşünüş ve hakikati temel bir referans noktası alma çabasının ardında onun günümüz koşulları çerçevesinde felsefeye verdiği değer ve gereklilikten ileri gelir. Ona göre dünyanın içinde bulunduğu dört temel gerekçe felsefeye neden gereksinim duyduğumuzu izah etmektedir.

İlk neden, önceki yüzyıllarda felsefenin yerini aldığı iddia edilen beşeri bilimlerin böyle bir ihtimalden uzak olmaları, bu bilimlerin salt istatistiksel analizlerden ibaret kalmalarıdır. Badiou'nun vurguladığ üzere, beşeri bilimler anlam dolaşımına ve anlamın çok değerliliğine kapılmış bir durumdadırlar ve temelde anketlere, seçim tahminlerine, demografik ortalamalara, epidemiyolojik oranlara, beğenilere ve hoşnutsuzluklara hizmet ediyorlar. Fakat bu hizmetin, insanlığın ya da bütünüyle tekil her varlığın ne olduğu hiçbir ilişkisi bulunmamaktadır. Badiou açısından son tahlilde bir önemi olan her türlü kararın merkezi tekil olandır her zaman ve her türlü hakikat -bilimsel icatlarda, sanatsal yaratımlarda, siyasi yeniliklerde ya da aşkı meydana getiren karşılaşmalarda görülebileceği gibi- önce mutlak tekil biçiminde sunulur. Bir şekilde bir hakikatin doğduğu beyan edilen her yerde hakikat tekillik üzerine kuruludur. Ortalamalar, istatistikler, sosyoloji, tarih, demografı ya da anketler bize bir hakikatin tarihinin ne olduğunu öğretemezler. Bu bakımdan Badiou'ya göre dünyanın felsefeden isteği bir tekillik felsefesi olarak tekil olanı telaffuz etmesi, düşünmesidir ki bu beşeri bilimlerin gerçekleştirebileceği bir görev değildir (2016, s. 22-23).

İkinci neden, modern zamanlarda özgürleşme ve hakikatin tohumlarını taşıdığını iddia eden büyük kolektif girişimlerin çöküşünün yol açmış olduğu koşullardır. Badiou'nun değindiği üzere, günümüz koşullarında büyük özgürleştirici kuvvetlerin olmadığını, ortada sanıldığı üzere bir ilerlemeden, proletaryadan söz edilemeyeceğini bilmekteyizdir. Bu durum, sadece filozofların değil hepimizin karşılaşmış olduğumuz 
çeşitli insanlık-dışı mevzular karşısında kendi kararımızı kendimizin vermesi ve kendi adımıza konuşmamız gerektiğini bildiğimiz anlamına gelir. Ayrıca bu bilinçle, herhangi bir büyük kolektif konfigürasyonun, herhangi bir farazi kuvvetin, bizim yerimize konum alabilecek herhangi bir metafizik bütünlügün ardına saklanamamaktayız. Fakat Badiou post-modern büyük anlatı yıkımı efsanesinin yol açmış olduğu ahlaki ve politik tavır alışı mümkün kılacak merkezi bir noktanın belirsizliği krizine tutulmama gayesiyle insanın karşı karşıya kaldığı çeşitli insanlık dışı olaylar karşısında kendi adına da olsa bir konum alabilmesi için karar vermeyi sağlayacak sabit bir noktanın gerekliliğini şart koşar. Ona göre, hem kararı hem de rızayı kurala bağlayacak koşulsuz bir ilkeye ihtiyaç bulunmaktadır (2016, s.23). Dolayısıyla Badiou açısından hakikat boyutunu içeren bir felsefeyi yeniden devreye sokmadan her birimizin kendi adımıza konum almamız gerektiği söylenemez. Şu anki haliyle dünyanın talep ettiği şey hakikat boyutunu devreye sokma işlemidir ve bu da felsefeden talep edilmektedir (2016, s.24). Her ne kadar post modernliğin temelci, evrensel ve nesnel değerler anlayışına yönelik yapıbozumcu yaklaşımının yol açmış olduğu değerler krizini aşma çabasında olmasına karşın Badiou bir yandan da büyük anlatıların yıkımını onaylar. Bu durumda büyük metafizik değerler sistemi veya özgürlük-eşitlik anlatıları üzerinden mevcut olana karşı durmak mümkün olamayacağı için sabit noktayı kişinin-öznenin kendisi devreye sokacaktır. Bu bakımdan hakikat inşası da Badiou'nun yaptığı gibi felsefenin dört koşulunun hakikatleri çerçevesinde gerçekleştirilecek bir düşünsel etkinlik olarak sunulduğu da dikkate alındığında Badiou'nun Postmodern kaosu aşma çabasının öznel bir girişim ve umut olarak kaldığı görülür. Dolayısıyla bu öznel girişimin ne derece evrensel ve kuşatıcı olabileceği problemi karşımıza çıkmaktadır. Badiou siyasal sorunlara klasik bir değer olan Adalet ilkesi üzerinden yaklaşmayı seçse de adaletin ne olduğu ve somut bir durumda nasıl uygulanması ve ele alınması ayrıca bir problem olarak kendisini sunar.

Badiou açısından üçüncü neden, son zamanlarda arkaik ihtirasların yükselişe geçmesiyle, yani kültürel, dini, milli ve ırkçı ihtirasların yükselişe geçmesiyle bağlantılıdır. Tarihsel olarak gözlemlenebilen bu fenomenler de felsefeye yönelik bir talep yaratmıştır. Bu ihtiraslarla bir kez daha karşı karşıya gelen felsefe aklın nerede olduğu hakkında konuşmaya mecburdur, zira bu ihtiraslar irrasyonel arkaizmin günümüzde büründüğü biçimlerdir ve beraberlerinde ölüm ve yıkım getirirler. Felsefenin günümüz rasyonalitesi hakkında bir beyanda bulunması gerekir. Bununla birlikte 
Badiou'ya göre konuşulması gereken rasyonalite, klasik rasyonalitenin bir tekrarı olmamalıdır. Fakat bu arkaik ve gerici ihtirasların apaçık tehdidi karşısında aşırı bir entelektüel bir zafiyet konumundan sıyrılabilmek için bu rasyonalitenin kurulabilmesi kaçınılmaz bir gerekliliktir (2016, s.24).

Badiou'da felsefenin gerekliliğine ilişkin dördüncü neden, içinde yaşadığımız dünyanın yaralanmaya açık, istikrarsız bir dünya olmasıdır. Ona göre bu dünya kendi tarihinin birliği içinde istikrardan uzak bir dünya olmakla birlikte onun israrla vurguladığ 1 gibi Liberal ekonomi ve temsili demokrasi temalarının genel kabul görür hale gelmiş olmasının, yirminci yüzyılın doğurduğu dünyanın şiddet dolu ve kırılgan bir dünya olduğu gerçeğini gizlemesine izin vermemeliyiz. Bu dünya büyük ilerleme anlatılarının aksine çizgisel bir gelişimin sükûnetini değil, bir dizi dramatik kriz ve paradoksal olay sergiler. Bu bakımdan, Badiou'ya göre olup bitenlerin indirgenmez tekilliğine açık bir felsefeye, beklenmedik olanın getirdiği sürprizle beslenebilecek bir felsefeye ihtiyacımız bulunmaktadır ve böyle bir felsefe onun tanımlanmasında olay felsefesi olacaktır (2016, s.24-25).

Badiou açısından sonuç olarak dünya bugün için bir tekillik felsefesi, bir çağdaş rasyonalite felsefesi ve bir olay felsefesi talep etmektedir. Bunu gerçekleştirebilmek için öncelikli olarak çağın üç felsefi yönelimin aşılması, ötesine geçilmesi gerekmektedir. Ona göre, belirlenmiş ve daha buyurucu bir felsefeye, ama aynı zamanda daha mütevazı, dünyaya daha mesafeli ve daha betimleyici bir felsefeye, Olayın tekilliği ile hakikati rasyonel bir biçimde iç içe geçiren bir felsefeye ihtiyacımız bulunmaktadır. Descartes 'tan Hegel'e dek uzanan özne anlayışının ötesinde yeni bir özneyi sunacak olan bu felsefede özne evrensel değil tekil olacaktır. Çünkü Badiou açısından her zaman özneyi bir hakikat olarak kuran bir olay olacaktır. Nihayetinde Badiou'nun gözünde dünya, felsefenin metafiziğin yıkıntıları üzerinde, çağdaş metafizik eleştirisiyle birleşip kaynaşmış bir biçimde yeniden kurulmasını ihtiyaç duymaktadır (2016, s.25).

Badiou kendi tutumunu çağdaş döneme özgü bir Platonculuk olarak tanımlar. ÇağdaşPlatonculuk, hermeneutikekolünönemlibirtemsilcisinde görüldüğü gibi hakikat veya varlık arayışının şiirde bulunma gayretini kritiğe tabi tutmayı ifade eden şairlerin çağının sona erdiğini kabul etmek, analitik ekolün tek yönlü matematiksel dilinin aksine matematiğin çağdaş biçimlerini ontolojinin vektörü olmaya çağırmak, aşkı psikanalizin felsefeyi tehdit eder biçimlerinden farklı şekilde hakikat işlevi içinde düşünmek ve 
nihayet politikanın adalet ilkesi çerçevesinde yeniden ele almaktır.(2015b, s.97-99). Badiou açısından, Platon'da benzer biçimde Sofistlere, Hesiodos benzeri şairlere karşı felsefeyi ve hakikati temsil etmiştir. Platon, Badiou için felsefe ve hakikat bağlamında kilit bir yer ve değere sahiptir. Badiou açısından felsefenin ve hakikat bilgisinin çağ içinde bulunduğu kriz durumundan sıyrılabilmesi bakımından önemli bir yere sahip olan Platon bu dünyadaki hayatımıza yön verebilmemiz için mutlak olana bir şekilde erişmemiz gerektiği inancına hayat veren kişidir. Badiou'ya göre, bugün ne yukarılarda hakikatlere nail bir Tanrıdan ne de insanların Mutlak'ın tarihsel özne-oluş figürlerinden olmasından söz edilemeyeceği pek açıktır. Bu durumda, dokumuzu oluşturan duyumsanabilirin, bireysel bedensellik ve retoriğin ötesine geçerek, ebedi hakikat fikrinin inşası için bir temel arayışı kaçınılmazdır ki her türlü eleştiriye karşın Platon hakikat fikri açısından dikkate değer bir temel olarak ele alınır (Badiou 2015d, s.10). Ayrıca Badiou açısından Platon felsefenin ve hakikatin dört temel koşulu çerçevesinde felsefesini oluşturmuş ve bu felsefi sistem, dört koşulun tam da Badiou'nun vurguladığı üzere birlikte mümkün olabilirlik çerçevesinde gerçekleştirilmiştir. Badiou'ya göre, Platon, sofistik olanın işbirlikçileri olan şairleri felsefenin kuruluş projesinin dışında tutarak şairler çağının sona erdiğini ilan eder, irrasyonel sayılar probleminin matematiksel olarak ele alınışını logos vizyonuna dahil eder, Güzele ve İdea'ya yükselişte aşkın aniliğine hakkını teslim eder ve nihayet politikanın bir başlangıç yollarını adalet ilkesince düşünülmesi gerektiğini ifade eder (2015b, s.97). Ayrıca Platon'u felsefenin dört arzusu bağlamında ele aldığımızda Platon'nun içinde bulunduğu toplumun etik ve politik durumuna, yozlaşmış haline karşı derin bir isyan duygusu içerisindedir. Fakat bu isyan başıboş, üstün körü bir tavra değil rasyonel ve mantıklı bir duruşa yol açmıştır. Bu duruş felsefenin evrensel ve nesnel bir zeminde herkese ama hakikat ideali bağlamında seslenen bir sistem biçimi almasına zemin hazırlamış ve Sofistik göreceliğin aşılması yolunda adım atmaya çalışmıştır. Şüphesiz hocası Sokrates'in ahlaksızlık yaydığı gerekçesiyle demokratik yönetimce idam edilmesine karşın var olanı ciddi bir şekilde kritiğe tutmasıyla ve demokrasiye dair eleştirileriyle Platon aynı zamanda akışa aykırı davranarak risk almış olur.

\section{Sonuç}

Temelde bilgelik sevgisi veya bilgi peşinde olma olarak ele alabileceğimiz felsefenin bu belirlenimi veya tanımı gereği hakikat talebi göz ardı edilemeyecek derecede önemli bir değere sahiptir. Varlığın veya doğanın 
kökenini sorgulayan ilk filozoflardan günümüze değin ister varlık sorunsalı ister doğruluk veya gerçeklik problemi çerçevesinde şekillensin felsefede hakikat arayışı dikkat çekici bir yere sahiptir. Elbette ki birbirinden çok farklı dünya görüşlerinin veya tarihsel devirlerin, felsefi eğilimlerin temelde felsefeye ve hakikat sorunsalına yönelik bakış açları birbirinden kökten şekilde farklı cevapların, açıklama girişimlerinin sergilendiği görülür. Bununla birlikte özellikle de Postmodernliğin etkisiyle felsefenin ve onun temel arayışı olarak hakikat talebinin sonu ilan edilir. Aslında dünya ve insan üzerine genel bir çerçeve sunmayı ifade eden geleneksel felsefe olarak metafiziğin veya üst-anlatıların radikal bir şekilde kritiğe tabi tutularak sonlarının ilan edildiği ve felsefenin ya dilsel bir analize veya yorumbilimsel bir çabaya indirgendiği görülür. Böylesine bir dönemde Badiou, felsefenin özellikle de sistematik felsefenin ve metafiziğin sonunun ilan edildiği, teorik olarak çok anlamlılık ve dil oyunlarının, politik açıdan ise liberal dünyanın sunduğu biçimde bir özgürlük ve eşitlik anlayışının hüküm sürdüğ̈ kaotik bir dünyada felsefenin, hakikat fikrinin ve adalet talebinin bir savunusu olarak karşımızda durur. Bu savunu onun adlandırılmasıyla çağdaş bir Platonculuktur. Platoncu'dur zira hermeneutik yorumsamacı ekolün bilhassa Heidegger' in varlığı ve hakikati şiirde aramasına karşın temelini matematiğin inşa ettiği felsefi bir dili, post-modern çok anlamlılığa, hakikat yoksunluğuna karşın bir hakikat fikrinin var olduğunu, aşkı Lacan'c1 veya Neo- Freudyen eğilimlere karşın hakikat fikri içinde düşünmeyi ve nihayet adalet talebini içerir. Bununla birlikte, Badiou tutucu ve romantik bir Platoncu değildir, bu Platoncu tavır felsefenin dört temel koşulu olan aşk, siyaset, sanat ve matematikteki dönüşümleri, kritikleri ve olayları dikkate alan bir tavırdır. Dolayısıyla klasik felsefenin tutucu ve totaliterliğe zemin hazırladığ 1 düşünülen Bir- Varlık anlayışına ve hakikatin her şeyi kuşattı̆̆ inancına yönelik çağdaş eleştirilerin farkındadır. Bu bakımdan çokluğu ve sonsuzluğu matematikteki çağdaş kümeler kuramı aracılığıyla içinde boşluk ve sinırın olduğu olay felsefesi bağlamında ele alarak bir yandan hakikat fikrini müdafaa ederken öte yandan eleştiriler de önemsenmiş, dikkate alınmış olunur.

Şüphesiz Postmodern anlamlar veya yorumlar çokluğuna ve son fikrine karşın felsefi çaba ve hakikat tutkusunu muhafaza etme çabası içerisinde olmasına rağmen Badiou'da kritik etmemiz gereken en temel sorun öncelikli olarak talep edilmesine karşın hakikatin tanımlanamaz olması iken hakikatin koşulları karşısında karar vermesi beklenmesi gereken öznenin hangi olayları kendisine referans alması gerektiğidir. 
Badiou felsefenin veya hakikatin koşulları bağlamında çeşitli olayları, metinleri veya isimleri belli bir küme etrafında bir araya getirmeye çalışır. Elbette ki bu, öznel bir girişim olarak kendisini sunarken Postmodern yorumlar çokluğunu ne denli aştı̆̆ ise dikkate değer bir sorun olarak kalır. Ayrıca çağdaş bir rasyonalite çabasının tikel olarak tanımlanan ve hakikati kurmak veya tanımlamaktan ziyade olay karşısında karar vermesi beklenen tikel bir özne ile ne şekilde mümkün olabileceği ve bu tikel öznenin hakikat sorunsalı karşısında ele aldığı olayın tam da istenilen veya olması gereken olay olup olmadığı da tartışılmaya açıktır. Özellikle de savunulması gereken adalet fikrinin salt tikel bir özneden ziyade genel olarak insanlık sorunlarıyla ilgili nesnel ve evrensel bir fikir olabilmesi tikel öznelerin hangi ortak değeri, ilkesi veya vasfı üzerinden mümkün olabilecektir?

Badiou, hakikat fikrini ve felsefeyi politika, şiir, aşk ve matematik olarak belirlediği dört temel koşul üzerinden inşa etmeye veya oturtmaya çalışır. Bunu yaparken de her bir koşul açısından referans aldığı temel olaylar, kişiler veya metinler bulunmaktadır. Bu bakımdan bir başka tikel özne olarak her bir koşulda referans alıp kendisine sadakatle bağlanacağımız olay, metin veya eser bizi Badiou'nun ulaşmak istediği fakat tanımlayamadığı hakikate taşımaması durumunda kaçınılmaz olarak Badiou'nun eleştirdiği yorumlar-anlamlar çokluğunun içine sürükleyecektir.

Sonuç olarak, Alain Badiou felsefesi felsefenin ve hakikat fikrinin bütün son ilanı ve kriz duyurularına karşın var olan koşullar dikkate alınacak bir biçimde bir savunusudur. Bu savunu aynı zamanda Platon'un çağdaş sofizmin temellerini inşa eden başlıca isimler olarak Heidegger, Nietzsche, Derrida, Lyotard ve Popper'a karşı bir savunusu olarak kendisini kurar. Nihayetinde Badiou'nun hakikat arayışı, postmodernliğin geleneksel felsefeye veya modernliğe yönelik hakikatin tekliği ve değerlerde evrenselik ile temelci-özcü yaklaşım çerçevesinde sunduğu kritiği dikkate alırken öte yandan hakikat tutkusu ve adalet fikrinin felsefenin vazgeçilmez birer dokusu olduğu da göz önünde bulundurularak yapılan ve sürekli olarak çeşitli olaylar çokluğu karşısında yeniden gözden geçirilen bir arayıştır. Bununla birlikte, bu arayış felsefe ve hakikat fikrine yönelik umudu, tutkuyu çeşitli sorun ve çelişkilerle birlikte içerir.

Adnan Akan, Kocaeli Üniversitesi, Türkiye 


\section{Kaynakça}

Badiou, Alain. (2008). Conditions, çev. Steven Corcoran, New York: Continuum International Publishing Group.

Badiou, Alain. (2015a). Fransız Felsefesinin Macerası, çev. Burcu Yalım, İstanbul: Metis Yayınları.

Badiou, Alain. (2015b). Felsefe İçin Manifesto, çev. Murat Erşen, İstanbul: Monokl. Badiou, Alain. (2012). Felsefe ve Politika Arasındaki Gizemli İlişki, çev. Murat Erşen, İstanbul: Monokl.

Badiou, Alain. (2015c). Gerçek Mutluluğun Metafiziği, çev. Murat Erşen, İstanbul: Monokl Yayınevi.

Badiou, Alain. (2010). İdeası Komünizm Olan Şeyin Gerçeği, çev. Savaş Kılıç, Okan Doğan, Haluk Barışcan, Komünizm Fikri içinde, İstanbul: Metis Yayınları.

Badiou, Alain. (2014). Platon'un Devleti, çev. Savaş Kılıç, Nihan Özyıldırım, İstanbul: Metis Yayınları.

Badiou, Alain. (2006). Plato Our Dear Plato, çev. Alberto Toscano, Angelaki 11:3.

Badiou, Alain. (2006). Polemics, çev. Steve Corcoran, London: Verso.

Badiou, Alain. (2016). Sonsuz Düşünce, çev. Tuncay Birkan- Işık Ergüden, İstanbul: Metis Yayınları.

Badiou, Alain. (2009). Who Is Nietzsche, Erişim Tarihi: 17 Haziran 2016, http:// plijournal.com/papers/alain-badiou-who-is-nietzsche/.

Badiou, Alain. (2013). Yeni Siyaset İçin Felsefe, çev. Barış Özkul- Erkal Ünal, İstanbul: Encore.

Badiou Alain - Zizek Slavoj. (2005). Philosophy in The Present, Cambridge: Polity Press. 